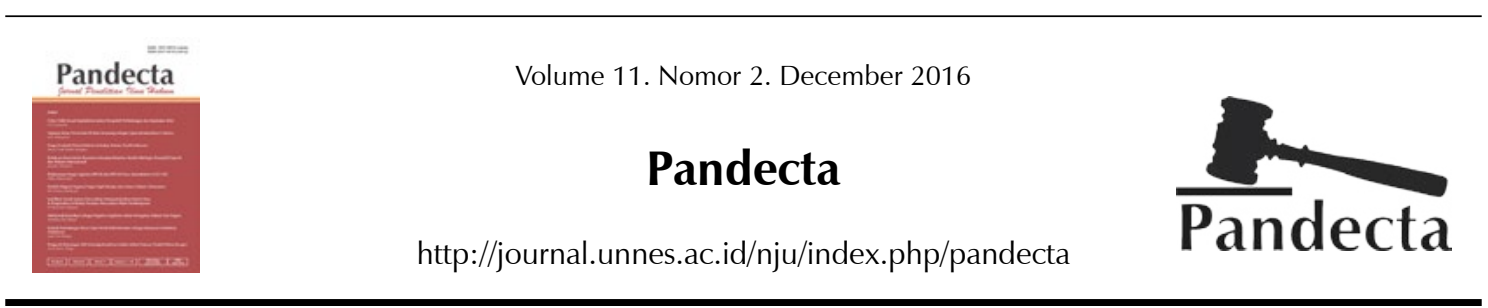

\title{
Syariat Islam dalam Perspektif Negara Hukum berdasar Pancasila
}

\author{
Nurrohman Syarif \\ Hukum Tata Negara (Fiqh Siyasah), Universitas Islam Negeri (UIN) Sunan Gunung Djati, Bandung \\ DOI: http://dx.doi.org/10.15294/pandecta.v11i1.7829
}

\begin{tabular}{l} 
Info Artikel \\
\hline Article History: \\
Received : June 2016; \\
Accepted: November 2016; \\
Published: December 2016 \\
\hline Keywords: \\
Ideology of Pancasila; State \\
law; Islamic Sharia \\
\hline
\end{tabular}

\begin{abstract}
Abstrak
Revitalisasi ideologi dalam perspektif Islam, baik pada tingkat nasional maupun global selalu bermuara pada aspirasi dan tuntutan untuk mengimplementasikan syari'at atau hukum Islam secara total (kaffah). Dalam Negara hukum Indonesia, aspirasi dan tuntutan semacam itu tidak selalu bisa dipenuhi. Hal ini karena Negara hukum Indonesia, sejak awal dibangun atas dasar semangat kebangsaan yang didasarkan atas prinsip ketuhanan, kemanusiaan, keadilan, dan kesetaraan atau persamaan bagi setiap warga Negara didepan hukum. Oleh karena itu aspirasi dan tuntutan penerapan syariat Islam selalu mengalami kendala bila didalamnya terdapat unsur diskriminatif atau unsur lain yang dapat menghilangkan jaminan dan perlindungan terhadap hak asasi warga negara yang sudah dijamin oleh konstitusi. Penelitian ini akan menjelaskan tentang pengertian dan karakter syariat, tujuan syariat, modelmodel penerapan syariat di sejumlah Negara Muslim, model atau teori penerapan syariat Islam di Indonesia menurut sejumlah pakar, pilihahan atau alternative yang bisa digunakan untuk memperjuangkan aspirasi dan tuntutan implementasi syariat Islam di Indonesia dan ditutup dengan simpulan.
\end{abstract}

\begin{abstract}
Revitalization of ideology in Islamic perspective, both at national and global level always leads to aspirations and demands to implement sharia or Islamic law in total (kaffah). Within the legal State of Indonesia, such aspirations and demands can not always be met. This is because the Indonesian state of law, from the beginning built on the spirit of nationality based on the principle of divinity, humanity, justice, and equality or equality for every citizen in front of the law. Therefore, the aspirations and demands of the application of Islamic Shari'a always experience constraints if in it there are discriminative elements or other elements that can eliminate the guarantee and protection of citizens' rights that have been guaranteed by the constitution. This paper will explain the understanding and character of the Shari'a, the purpose of Shari'a, models of Shari'a application in some Muslim countries, the model or theory of application of Islamic Shariah in Indonesia according to some experts, alternatives or alternatives that can be used to fight for aspirations and demands of the implementation of Islamic Shariah Indonesia and concluded.
\end{abstract}

(c) 2016 Universitas Negeri Semarang ISSN 1907-8919 (Cetak) ISSN 2337-5418 (Online) 


\section{Pendahuluan}

Hubungan agama dan kekuasaan atau negara merupakan hubungan yang rumit dan unik dalam sepanjang sejarahnya. Dalam sejarah Islam, kerumitan dan keunikan itu bisa ditelusuri sejak kehidupan Nabi Muhammad SAW. Secara pribadi, beliau sendiri menyatakan bahwa beliau diutus untuk menyempurnakan akhlak. Dengan kata lain, misi beliau adalah misi etik dan moral bukan misi politik. Beliau dengan konsisten menolak tawaran "jabatan" politik sewaktu masih berada di Mekkah. Akan tetapi sewaktu beliau berhijrah ke Madinah, beliau dipercaya untuk menduduki posisi yang oleh sebagian pakar dianggap sebagai posisi seorang kepala Negara. Meskipun sebagian pakar seperti Ali Abd al-Raziq (1985) dalam bukunya al-Islam wa Ushul al-Hukmi berpandangan bahwa Nabi Muhammad tetap sebagai pemimpin moral bukan pemimpin politik, tetapi sebagian pakar lainnya berpandangan bahwa Muhammad SAW, sewaktu pindah ke Madinah sebenarnya telah menjadi negarawan atau kepala Negara. Melalui bukunya yang berjudul: Muhammad Prophet and Statesman, Montgomery Watt (1961: 94-95), mencoba mempertahankan pandangannya bahwa Muhammad bukan hanya seorang Nabi tapi juga negarawan. Bagi Raziq, kepemimpinan Muhammad di Madinah tetap merupakan kepemimpinan moral dan masyarakat Madinah yang dipimpin oleh Muhammad pada waktu itu belum atau tidak layak disebut $\mathrm{Ne}$ gara. Sementara bagi Watt, Muhammad sewaktu di Madinah bukan hanya sebagai Nabi tapi sekaligus sebagai negarawan atau kepala Negara. Meskipun dalam bentuk yang masih sederhana, Madinah pada zaman nabi memenuhi syarat disebut Negara.

Dampak atau akibat dari keunikan ini, para pakar dalam Islam berbeda dalam banyak hal. Misalnya, apakah Negara Madinah merupakan Negara agama (religious state) atau Negara sipil (civil state). Bagaimana bentuk pemerintahan atau Negaranya, apakah bisa disebut pemerintahan yang teokratis, atau demokratis. Kalau mandat yang diterima oleh Muhammad sebagai nabi diperoleh dari Tuhan melalui wahyu, apakah mandat yang diperoleh beliau untuk memimpin Madinah juga diperoleh dari wahyu, atau dari rakyat Madinah atas dasar karakter pribadinya. Walhasil, keunikan ini berdampak pada perbedaan pakar dalam merumuskan berbagai hal: bentuk negara Madinah; relasi agama dan negara; relasi hukum Islam dan negara; definisi Darul Islam atau Negara Islam; cara negara-negara Muslim menempatkan hukum Islam dalam konstitusi Negara masingmasing; serta model pelaksanaan syariat Islam di masing-masing negara.

Di dunia Islam sendiri, terutama semenjak masuknya ideologi-ideologi besar dunia, sikap umat Islam termasuk para pakarnya secara garis besar terbagi dua. Pertama, pihak yang ingin tetap mempertahankan Islam sebagai agama, sebagai petunjuk moral, etik dan spiritual bagi umatnya, Kedua, pihak yang ingin menjadikan Islam bukan sekedar agama tapi juga sebagai ideology. Dengan dijadikannya Islam sebagai ideology, maka ia tidak hanya bersaing tapi juga terkadang berbenturan dengan ideology besar dunia termasuk dengan Pancasila yang dijadikan dasar dan ideology Negara Indonesia.

Gerakan-gerakan Islamism yang menjadikan Islam sebagai ideologi, baik pada tingkat nasional maupun global selalu bermuara pada aspirasi dan tuntutan untuk mengimplementasikan syari'at (hukum Islam) secara total (kaffah) melalui instrumen Negara.

Dalam Negara hukum seperti Indonesia, aspirasi dan tuntutan semacam itu tidak selalu bisa dipenuhi. Hal ini karena Negara hukum seperti Indonesia, sejak awal dibangun atas dasar semangat kebangsaan yang didasarkan atas prinsip, ketuhanan, kemanusiaan, keadilan, persatuan serta prinsip kesetaraan atau persamaan setiap warga Negara didepan hukum. Oleh karena itu aspirasi dan tuntutan penerapan syariat Islam selalu akan mengalami kendala bila didalamnya terdapat unsur diskriminatif atau unsur lain yang dapat menghilangkan jaminan dan perlindungan terhadap hak asasi warga negara yang sudah dijamin oleh konstitusi. Spirit konstitusi Indonesia adalah melindungi segenap bangsa Indonesia artinya, setiap warga Negara mesti mendapat perlakuan yang sama di depan 
hukum.

Permasalahan akan muncul bila aspirasi dan tuntutan untuk mengimplementasikan syariat Islam dilakukan hanya dengan menggunakan satu strategi saja. Dengan kata lain permasalahan akan selau muncul bila dalam upayanya memperjuangkan transformasi hukum Islam kedalam hukum nasional, para pendukung ideology Islam hanya menggunakan satu model. Untuk itu agar aspirasi dan tuntutan untuk mengimplementasikan syariat Islam bisa diakomodir, para pendukung "ideologi Islam" mesti merubah strateginya dalam memperjuangkan transformasi hukum Islam kedalam hukum nasional. Strategi yang digunakan adalah dengan lebih menekankan pada tujuan syariat, bukan pada pendapat perorangan atau pendapat madzhab tertentu. Strategi ini memungkinkan mereka untuk memilih dan menimbang sejumlah pandangan pakar hukum Islam yang begitu kaya dan beragam untuk disaring dan dipilih mana diantara pandangan itu yang lebih selaras dengan prinsip Negara hukum yang berdasarkan Pancasila tanpa harus menyimpang dari tujuan syariat.

Paper ini bertujuan menjelaskan pengertian syariat Islam, karakteristik dan tujuannya, penerapan atau implementasinya di sejumlah Negara Muslim, teori penerapannya di Indonesia menurut sejumlah pakar serta pilihan atau alternative yang bisa digunakan untuk memperjuangkan aspirasi dan tuntutan implementasi syariat Islam di Indonesia.

Penelitian ini berangkat dari konsep atau teori tentang hubungan agama dan politik atau Negara, yang kemudian diturunkan menjadi konsep hubungan syariat (hukum Islam) dan Negara. Teori tentang hubungan agama dan Negara yang digunakan dalam penelitian ini adalah teorinya Maskuri Abdullah.

Dalam tulisannya yang berjudul Agama dalam Pluralitas Masyarakat Bangsa yang dimuat di harian Kompas, Masykuri Abdullah (2000) mengatakan bahwa hubungan antara agama dan negara dapat diklasifikasikan kedalam tiga bentuk yakni integrated, intersectional dan separated. Hubungan integrated adalah hubungan yang menyatu antara aga- ma dan negara, dimana aturan-aturan agama secara otomatis menjadi aturan-aturan negara, dan kepemimpinan keagamaanpun sekaligus menjadi pemimpin negara, seperti praktek kenegaraan di Iran dan Vatikan. Hubungan intersectional adalah hubungan yang menggambarkan adanya persinggungan antara agama dan negara. Adakalanya persinggungan ini hampir sempurna, yakni jika hukum-hukum agama menjadi hukum positip sebuah negara, seperti praktek kenegaraan di Arab Saudi. Adakalanya persinggungan ini hanya sebagian saja, yakni jika sebuah negara hanya sedikit saja mengadopsi hukum agama menjadi hukum positip, seperti praktek kenegaraan di Indonesia. Hubungan sekularistik atau separated, adalah hubungan pemisahan antara agama dan negara seperti praktek kenegaraan di Turki dan sebagian besar dunia Kristen.

Sejalan dengan variasi hubungan agama dan politik, peran agama dalam politik juga bervariasi. Peran agama dalam politik bisa diklasifikasikan kedalam tiga bentuk. Pertama agama sebagai ideologi politik, kedua agama sebagai landasan etika, moral dan spiritual dan ketiga agama sebagai sub-ideologi. Negara yang menempatkan agama sebagai ideologi, cenderung akan melaksanakan ajaran agama (syari'at dalam konteks Islam) secara formal sebagai hukum positip serta melakukan pendekatan struktural dalam sosialisasi dan institusionalisasi ajaran agama. Negara yang menempatkan agama sebagai sumber etika, moral dan spiritual cenderung akan mendukung pendekatan kultural dan menolak pendekatan struktural dalam hal sosialisasi dan institusionalisasi ajaran agama. Artinya pelaksanaan ajaran agama tidak perlu dilembagakan melalui perundang-undangan dan dukungan negara, tetapi cukup dengan kesadaran umat Islam atau umat beragama sendiri. Negara yang menempatkan agama sebagai subideologi cenderung akan mendukung pendekatan kultural sekaligus struktural, yakni dengan melibatkan ajaran agama dalam pengambilan kebijakan publik dengan cara yang konstitusional dan demokratis secara tidak diskriminatif. 


\section{Metode Penelitian}

Penelitian ini tergolong library research atau penelitian pustaka dengan jenis descriptive analisis. Artinya, data-data yang digunakan diambil dari buku atau bahan pustaka. Pengertian syariat, tujuan dan karakteristiknya, diambil dari sumber utama ajaran Islam yakni al-Qur'an serta penafsiran para pakar dalam kitab tafsir atau figh (hukum Islam). Demikian pula tentang implementasi syari'at Islam disejumlah Negara Muslim, dan teori penerapannya di Indonesia. Semuanya, kemudian dianalisa dengan teori hubungan agama dan politik serta teori tentang model penerapan syariat Islam. Semua analisa digunakan untuk merumuskan strategi penerapan syariat Islam yang sejalan dengan Negara hukum yang berdasar Pancasila.

\section{Hasil dan Pembahasan}

\section{Syariat Islam, Karakteristik dan Tujuannya}

Syariat atau kata yang memiliki akar kata yang sama disebut dalam al-Qur'an sebanyak lima kali, yakni pada surat al-Syura (42) ayat 13 dan ayat 21, al-A'raf (7) ayat 163 , al-Ma'idah (5) ayat 48 dan surat al-Jatsiyah (45) ayat 18 . Kata ini pada mulanya bermakna jalan menuju sumber air yang berarti sumber terpenting bagi kehidupan. Syari'at dalam bentuk kata kerja syara'a artinya membuat garis atau tanda yang jelas menuju tempat air. Penggunaannya dalam agama, sejak periode pertama, adalah jalan lebar atau luas untuk menuju kehidupan yang baik. Didalamnya terdapat nilai-nilai agama yang secara fungsional bisa digunakan untuk mengarahkan kehidupan manusia.

Sejak awal, aspek praktis merupakan bagian dari konsep syariah. Ia merupakan jalan yang digariskan Tuhan untuk dijalani manusia dalam kehidupannya agar sesuai dengan kehendak Tuhan. Syariat adalah konsep praktis untuk berprilaku. Tapi ia juga meliputi prilaku fisik, mental dan spiritual. Jadi ia meliputi keyakinan dan tindakan. Keyakinan akan adanya Tuhan Yang Satu adalah bagian dari syariah sebagaimana kewajiban agama seperti shalat, puasa, zakat dan haji. Pada perkembanganan selanjutnya semua transaksi hukum dan sosial termasuk prilaku pribadi dimasukkan kedalam syariat atas dasar prinsip komprehensif dari cara hidup yang total.

Dalam bukunya yang berjudul: Maqasid al Shariah as Philosophy of Islamic Law A Systems Approach, Jasser Auda (2007: 5658) menjelaskan beberapa istilah yang saling berkaitan seperti hukum Islam (Islamic law), syariat, fiqh, qanun dan 'urf. Istilah hukum Islam biasanya digunakan dalam literatur yang ditulis dalam Bahasa Inggris untuk merujuk kepada istilah fiqh, syariat, qanun dan 'urf. Kata fiqh dalam berbagai bentuknya digunakan oleh al-Qur'an maupun hadits untuk menunjukkan pemahaman dan pengetahuan keagamaan secara umum. Pada ujung era Imam Madzhab, kata figh kemudian dimaknai sebagai pengetahuan tentang aturanaturan praktis dari dalil-dalil yang terperinci. (al-ilmu bi al-ahkam al-syar'iyyah al-amaliyyah min adillatiha al-tafshiliyyah). Artinya fiqh kemudian dibatasi maknanya untuk aturanaturan parktis, tidak termasuk hal-hal yang terkait dengan keyakinan atau teologi.

Kata qanun berasal dari Bahasa Persia yang kemudian mengalami proses arabisasi. Kata ini pada mulanya berarti prinsip atau pokok. Sejak abad kesembilan belas, kata ini diberi arti hukum tertulis di Negara-negara yang menjadikan Islam sebagai sumber legislasi. Sedangkan 'urf adalah kebiasaan atau lebih tepatnya kebiasaan baik yang telah diterima oleh masyarakat tertentu. Sanksi atau hukuman bagi seseorang yang melanggar ketentuan hukum Islam atau figh, tidak selalu berbentuk sanksi duniawi. Sanksi utama yang akan diterima adalah sanksi akhirat. Umat Islam sebagaimana umat beragama pada umumnya, meyakini bahwa kehidupan ini bukan hanya kehidupan di alam dunia yang fana ini. Setelah kematian, ada kehidupan yang kekal dan abadi.

Dalam bahasa Inggris, fiqh juga sering diterjemahkan menjadi sharia law atau hukum syara. Dalam Bahasa Indonesia, istilah hukum Islam digunakan sebagai istilah yang mencakup fiqh, syari'at dan qanun. Meskipun hukum Islam meliputi syari'at dan fiqh, namun kedua istilah ini bagi umat Islam memiliki tingkat kesakralan yang berbeda. Sebab hukum syara didefinisikan oleh ulama ushul sebagai khitab Allah al-mut'alliqu bi 
af'al al-mukallafin (firman Tuhan yang terkait pebuatan manusia dewasa dan berakal sehat). Firman Tuhan ini ada yang berupa tuntutan yang sifatnya membebani, ada yang berupa pilihan dan ada pula yang berupa sebab, syarat atau penghalang. Tuntutan keharusan untuk dilaksanakan disebut wajib, tuntutan bersifat untuk ditinggalkan disebut haram atau larangan, tuntutan anjuran untuk melaksanakan disebut mandub atau sunnah sedangkan tuntutan anjuran meninggalkan disebut makruh. Adapun yang sifatnya pilihan, maka disebut mubah.

Sebagai firman Tuhan, hukum syara tentu sempurna, sakral, tidak mengandung kekeliruan. Namun, fiqh sebagai produk manusia dalam memahami firman Tuhan atau hukum syara tentu tidak sempurna. Itulah sebabnya, dalam bukunya yang berjudul Islam and the Challenge of Democracy, Khaled Abou El-Fadl (2004:34) mengatakan: shari'ah as conceived by God is flawless, but as understood by human beings is imperfect and contingent. (syari'at yang dikonsep Tuhan adalah sempurna, tapi syari'at yang dipahami oleh manusia tidak sempurna dan bergantung.)

Sebagai produk pemahaman manusia, figh atau hukum Islam tidak sempurna bahkan dalam beberapa hal berbeda antara fiqh yang digali oleh satu orang dengan figh yang digali oleh orang lain atau antara figh yang dikembangkan dalam satu madzhab dengan figh madzhab lain. Perbedaan itu bukan semata karena perbedaan teks ayat yang digunakan untuk menggali hukum Islam, tapi juga bisa karena perbedaan dalam memahami teks ayat yang sama. Perbedaan juga bisa timbul karena penggunaan metode penggalian hukum yang berbeda.

Melalui metode penggalian hukum yang dikembangkannya, para imam atau para sarjana hokum Islam disertai dengan para pengikutnya, akhirnya membentuk sebuah madzhab. Jadi para sarjana hokum atau ahli fighlah yang secara mandiri mengembangkan hukum Islam sekaligus sebagai artikulatornya.

Dalam tulisannya yang berjudul: Keeping The State Out: The Separation of Law and State in Classical Islamic Law, Lubna A Alam (2007:1255) mengatakan bahwa system hu- kum Islam tumbuh dari upaya individu yang saleh yang benar-benar ingin mengetahui kehendak Tuhan. Para individu yang didorong oleh komitmen agamanya lama-kelamaan membentuk lingkaran atau kelompok studi. Hampir seratus tahun setelah wafatnya Nabi Muhammad, atau sekitar tahun 730 Masehi, para individu yang memiliki pengetahuan luas dan terus mau belajar menjadi orangorang terdidik yang memiliki pengaruh lebih di masyarakat semata-mata karena ilmunya.

Para pakar ini menandingi otoritas $\mathrm{Ne}$ gara dalam bidang hukum dengan menempatkan diri mereka sebagai artikulator hukum (the articulators of the law). Jadi, otoritas hukum didasarkan atas pengetahuan yang dimiliki seseorang bukan pada kekuasaan, politik atau masyarakat. Mengingat kepakaran hukum yang menjadikan seseorang memiliki otoritas, maka otoritas hukum bersifat privat atau personal melekat pada diri para pakar dan komunitasnya (madzhab), bukan pada penguasa politik atau Negara.

Jadi, hukum Islam mewakili pandangan para ahli hukum. la dikembangkan oleh perorangan dan ilmu hukum (Ilmu Figh). Negara tidak ambil bagian dalam proses legislasi. Buku atau kitab karya para pakar lebih memiliki kekuatan hukum. Berbeda dengan peradaban lain termasuk peradaban Barat, dimana Negara berperan dalam proses legislasi dan eksekusi hukum, dalam peradaban Islam Negara tidak terlibat dalam mengelola hukum atau dalam proses menciptakan dan mengundangkan hukum.

Otoritas diluar system politiklah yang berperan menciptakan itu. Meskipun Negara tidak merumuskan hukum, Negara mengangkat hakim untuk melaksanakan hukum. Jadi, hukum tetap independen dari Negara tetapi pengadilan dalam system klasik tidak independen. "the Shari'a court [was] . . an apparatus of the state, but based on a law that [was] outside the state's domain." Demikian kata Alam.

Tidak semua pakar hukum merasa senang dengan pengangkatannya sebagai hakim, mengingat korupnya kekuasaan politik pada masanya. Banyak cerita tentang pakar yang menolak atau berusaha menghindar saat dirinya akan diangkat sebagai hakim. 
Abu Qilaba al Jarmi (wafat. 722 atau 723 Masehi) meninggalkan Bashra setelah mendengar dirinya diangkat sebagai hakim. Abu Hanifah, tokoh madzhab Hanafi, rela dipenjara dan dijilid karena menolak pengangkatannya sebagai hakim. Karena Negara tidak melakukan proses legislasi, maka perbedaan diantara pakar hukum terus tumbuh, namun hal ini dianggap sebagai rahmat dari Tuhan.

Pada masa dinasti Usmani, banyak terjadi perubahan penting tentang hubungan hukum dan Negara. Negara mulai mengontrol hukum melalui proses sentralisasi dan unifikasi syari'ah. Negara mulai terlibat dalam proses legislasi hukum (qanun) sebagai suplemen atas syari'at atau hukum Islam.

Sejak adanya perubahan tatacara pengorganisasian hukum, para hakim dalam Kerajaan Usmani memutus kasus berdasarkan syariat dan qanun. Berbeda dengan pengorganisasian hukum Islam di masa klasik, otoritas pembuatan qanun berada pada kekuasaan Negara untuk mengeluarkan hukum. Diversifikasi otoritas kemudian menuju kepada kesatuan otoritas. Jadi, otorits hukum berubah, dari semula dipegang oleh ahli hukum independen diluar Negara ( non state independent legal scholars) , beralih ke tangan Negara. Perubahan ini ikut memfasilitasi terjadinya proses modernisasi, westernisasi hukum dan Islamisasi hukum.

Dari penjelasan diatas, maka hukum Islam sebenarnya memiliki sejumlah karakter. Pertama, hukum Islam mengandung nilai sakral karena ia berasal dari Tuhan. Sebagai mana telah dijelaskan dimuka bahwa hukum Islam berasal dari firman Tuhan. Karakter kedua bahwa hukum Islam mengandung muatan moral. la tidak hanya berbicara hak dan kewajiban tetapi bebicara tentang apa yang sebaiknya diperbuat dan apa yang sebaiknya tidak diperbuat oleh seorang yang dewasa dan berakal sehat (mukallaf). Sebagai hukum agama, hukum Islam terkait dengan kesadaran beragama yang dimiliki oleh seseorang. la juga terkait dengan kesadaran seseorang akan adanya pahala dan siksa di kehidupan akhirat setelah mati.

Proses desakralisasi terjadi saat syari'at diinterpretasikan atau dipahami oleh manusia. Proses desakralisasi juga terjadi pada saat hokum Islam mengalami proses politisasi dengan cara memaksakan hukum Islam melalui instrumen politik. Dengan kata lain, desakralisasi terjadi pada saat terjadi qanunisasi, dengan merubah syari'at atau hukum Islam menjadi qanun. Dampak negatif qanunisasi adalah bahwa orang mengikuti hukum Islam bukan karena kesadaran moralnya tapi karena dipaksa oleh negara. Modernisasi, westernisasi dan reislamisasi hukum melalui proses unifikasi dan sentralisasi syariat dapat berdampak pada hilangnya beberapa ciri atau karakter hukum Islam. Dijadikannya hukum Islam sebagai hukum positip di satu sisi menimbulkan kepastian tapi di sisi lain akan mengurangi fleksibilitas hukum Islam dan dapat berdampak pada hilangnya sebagian hak sipil dan hak politik warga. Bila hal itu terjadi, artinya ia gagal membawa visinya sebagai rahmatan lil alamin.

Karakter ketiga ialah bahwa hukum Islam pada dasarnya bersifat personal. Sebab ia terkait dengan keimanan. Artinya seseorang mengikuti petunjuk hukum Islam karena dorongan keimanannya kepada Nabi Muhammad atau kitab suci al-Qur'an. Setiap Muslim karena kesadaran imannya, bisa mengamalkan hukum Islam dimanapun ia berada. Hukum Islam bisa diamalkan di Negara Islam, di Negara sekuler atau di Negara Pancasila. Hanya aspek sanksi pidana saja yang memerlukan dukungan kekuasaan.

Karakter keempat, hukum Islam tidak sepenuhnya bergantung pada Negara tertentu. Sebab ia dikembangkan oleh para pakar hukum. Negara tidak merumuskan hukum, Negara mengangkat hakim untuk melaksanakan hukum. Sistem hukum Islam merupakan varian ketiga dalam dikhotomi antara civil law dan common law. Sistem Hukum Islam dapat disebut juristic law sebab hokum Islam dalam sejarahnya digali dan dikembangkan oleh para ahli hukum Islam atau para fuqaha mujtahid.

Dalam bukunya yang berjudul Modern Perspective on Islamic Law, Black, Ismaeili dan Hosen (2013:xi) mengatakan:

Islamic law is the world's third major legal system, after the common and civil law systems. Although the Qur'an and Sunna are the origi- 
nal sources of Islamic law, the Islamic legal system has evolved many other sources, methodologies and perspectives. Like any other legal system, the Islamic legal system has developed over many centuries in various Muslim societies, incorporating local cultures and customs as well as some limited state decrees and particularly the work of Muslim jurists... it was created and developed by private specialists; legal science and not the state, plays the part of legislator, and scholarly handbooks have the force of law. Islamic law is therefore neither common or civil law, but is juristic law.

Karakter kelima, hukum Islam fleksibel dan dinamis. Sebab ia pada dasarnya bisa berubah jika terjadi perubahan social. la dinamis karena bisa berkembang sesuai dengan perkembangan peradaban umat manusia. ljtihad (individual reasoning) tetap terbuka sepanjang masa. Karakter, keenam adalah bahwa ia rasional, sebab meskipun ia berasal dari firman Tuhan atau dari keyakinan, tapi dapat dipahami dan sejalan dengan akal sehat atau penjelasan sain.

Hukum Islam juga memiliki tujuan. Menurut sejumlah pakar, tujuan hukum Islam ialah untuk melindungi hak dasar manusia, menegakkan keadilan dan mendatangkan mashlahat atau kebaikan bersama.

Dalam kitabnya yang berjudul, I'lam al-Muwaqi'in, jilid III, Ibn Qayyim (Tanpa tahun:37) mengatakan sebagai berikut: fa inna al-syari'ata mabnaha wa asasuha 'ala hikamin wa mashalihi al-ibad fi al-ma'asy wa alma'ad wa hiya 'adlun kulluha wa rahmatun kulluha wa mashalihun kulluha wa hikmatun kulluha. Dalam mengomentari apa yang dikatakan oleh Ibn Qayyim, Jesser Auda (2007: xxii) dalam bukunya Maqasid al-Shari'ah as Philosophy of Islamic Law mengatakan sebagai berikut: Shari'ah is based on wisdom and achieving people's welfare in this life and the afterlife. Shari'ah is all about justice, mercy, wisdom, and good. Thus, any ruling that replaces justice with injustice, mercy with its opposite, common good with mischief, or wisdom with nonsense, is a ruling that does not belong to the Shari'ah, even if it is claimed to be so according to some interpretation.

Jadi syari'at dimaksudkan untuk men- ciptakan: keadilan (justice), kasih sayang (mercy), kebijakan( wisdom) dan kebaikan bersama (mashlahat). Secara tradisional tujuan syari'at ini diklasifikasi menjadi tiga level. Pertama, level dasar atau primer (dlaruriyat/ necessities), kedua level sekunder (hajiayat/ need), ketiga leve tersier (tahsiniyyat/ luxuries.) Level dasar /dlaruriyat itu meliputi perlindungan terhadap agama dan keyakinan (faith/ al-din),jiwa dan hak hidup ( soul/ alnafs), harta dan hak milik (wealth/ al-mal), akal dan kebebasan berpikir (mind/ al-aql), serta perlindungan terhadap keluarga dan keturunan (offspring/ al-nasl) . Ringkasnya, maksud syari'ah adalah menciptakan keadilan, kemashlahatan dan melindungi hak-hak dasar manusia.

Perlindungan terhadap kebebasan berpikir dan beragama dapat dilihat dari dua indikator berikut ini. Pertama, setiap orang terjamin kebebasannya untuk berpikir atau berijtihad sesuai dengan level dan kompetensinya masing-masing. Kedua, setiap orang terjamin kebebasannya untuk memeluk agama dan kepercayaan dan beribadah sesuai dengan agama dan kepercayaannya. Kebebasan beragama hanya bisa dibatasi pada aspek luar atau forum eksternum, bukan pada forum internum.

Adil (justice) indikatornya adalah: adanya persamaan dihadapan hukum (equality before the law) artinya siapapun yang sudah dewasa, berakal sehat maka ia memiliki kedudukan yang sama dihadapan hukum. Hikmah (wisdom) indikatornya adalah adanya sinergitas antara kebenaran logis rasional, kebenaran empiris, kebenaran mistik spiritual dan juga kebenaran pragmatis. Syariat atau hukum Islam disamping didukung oleh argumen logis rasional, fakta empiris, ia juga bisa mesti bisa dirasakan manfaatnya oleh si pengamalnya.

Adanya maslahat dapat diketahui dari sejumlah indikator antara lain: a) adanya dukungan atau kemanfaatan yang dirasakan oleh publik atau oleh manusia pada umumnya. Maslahat dalam kebijakan politik atau kebijakan publik bisa dijaring lewat opini publik atau tingkat kepuasan publik. Membawa rahmat indikatornya adalah adanya kemampuan untuk memberikan perlindungan 
terhadap minoritas, orang-orang yang tertindas dan terpinggirkan, orang- orang yang lemah kedudukannya di masyarakat. Adanya rahmat bisa diukur dari perlindungan terhadap hak asasi manusia yang diterima secara universal.

Melalui penggalian yang lebih dalam terhadap kandungan Al-Qur'an dan al-Hadits, dalam bukunya Democracy, Human Rights and Law in Islamic Thought, Mohammad Abed al-Jabri (2009:251) mengemukakan tujuh hak dasar manusia yang harus dilindungi oleh Negara atau masyarakat, yakni :1) hak hidup dan menikmati kehidupan (the right to life and its enjoyment) 2) hak berkeyakinan (, the rights to belief) 3) hak memperoleh pengetahuan (knowledge) 4) hak untuk tidak setuju (to disagree,) 5) hak bermusyawarah (alshura/consultation), 6) hak kesetaraan dan keadilan (equality and justice)7) hak orang-orang yang tertindas (the rights of the oppressed). Inilah hak dasar yang jika rakyat tidak bisa menikmatinya maka hukuman yang ada dalam syariat tidak bisa dilaksanakan dengan adil,kata Al-Jabri. Beliau menambahkan; Without putting an end to poverty, ignorance and the injustice of the rulers and the injustices of the strong against the weak, the hudud will remain exposed to doubt. And, the Prophetic hadith says, 'Avoid the hudud [penalties] when in doubt.'

\section{Penerapan Syariat Islam di Sejumlah Negara}

Dalam bukunya Filsafat Hukum Islam, Profesor Hasbi Ash Shiddieqy (1975: 73-92) mengatakan bahwa pembinaan dan pengembangan hukum Islam mesti didasari atas sejumlah asas yakni: 1) Nafyu al- kharaj atau meniadakan kepicikan. Hal ini sejalan dengan QS 22 al-Hajj ayat 78 dan QS 2 al-Baqarah ayat 286. 2) Qillatu al-taklif, menyedikitkan beban atau jangan memperbanyak larangan, karena ada kaidah al-ashlu fil asy'ya al-ibahah segala sesuatu pada dasarnya boleh. 3) sejalan dengan kemaslahatan manusia 4) mewujudkan keadilan yang merata 5) Mendahulukan akal atas dzahir nash atau teks syara jika terjadi pertentangan antar keduanya. 6) Masing-masing orang memikul tanggung jawabnya sendiri.
Di kalangan pakar hukum Islam, dikenal adanya lima kaidah pokok (legal maxim) atau panca qaidah yakni: 1) al umur bi maqashidiha, segala sesuatu tergantung pada tujuannya 2) al-dlarar yuzali, situasi darurat harus diatasi atau dihilangkan 3) almasyaqqah tajlibu al-taisir, kesulitan harus dijadikan pemicu untuk mencari cara yang lebih mudah 4) al-adat muhakkamah, adat istiadat memiliki kekuatan hukum 5) al-yaqin la yuzalu bil asyakk, keyakinan tidak bisa dihilangkan oleh keraguan.

Atas dasar prinsip pembinaan dan kaidah pokok yang terdapat dalam hukum Islam, penerapan hukum Islam di sejumlah Negara-negara Muslim tidak seragam. Hal ini karena masing-masing Negara memiliki sejarah sosial politik, politik hukum atau tradisi yang berbeda.

Secara umum ada tiga model penerapan syari'at Islam 1) model tekstualis eksklusif 2) substansialis inklusif dan 3) model kombinasi dari keduanya. Ketiga model ini bisa diterapkan secara bottom up atau top down.

Model pertama biasanya berusaha melaksanakan syari'at Islam sebagaimana telah disebutkan dalam teks al-Qur'an, al-Sunnah/ hadits atau dalam teks kitab-kitab mu'tabar yang diakui otoritasnya dalam menjelaskan hukum Islam. Model ini biasanya dilandasi dengan asumsi bahwa syari'at Islam telah sempurna mengatur segala aspek kehidupan. Syari'at Islam setelah nabi Muhammad tidak lagi mengalami proses evolusi. Oleh karena itu umat Islam tinggal menerapkannya bila ketentuannya sudah jelas dalam teks alQur'an atau al-Sunnah. Bila belum ada maka bisa menggunakan analogi/qiyas atau ijtihad. Umat Islam tidak perlu mengambil system hukum lain di luar Islam. Syari'at Islam merupakan hukum Tuhan yang tidak bisa diketahui maksud dan kandungannya secara benar kecuali oleh ahlinya, yakni faqih/pakar hukum Islam atau mujtahid. Oleh karena itu setiap undang-undang yang dibuat oleh lembaga legislative harus mendapat persetujuan dari ahli syari'at dan ahli syari'at berhak memveto setiap undang-undang yang dinilai tidak sejalan dengan syari'at.

Model kedua, berusaha mengamalkan syari'at Islam dengan melihat konsep atau 
gagasan yang ada dibalik teks. Bila gagasan utamanya telah ditangkap, maka penerapannya bisa dilaksanakan secara fleksibel sesuai dengan perkembangan zaman. Model kedua ini biasanya didasarkan pada asumsi bahwa setiap ketentuan hukum dalam hukum Islam ada reasoning-nya dan ada tujuannya. Oleh karena itu para pendukung model kedua ini tidak keberatan bila hukum Islam mengalami evolusi. Mereka juga relatif mudah menerima system hukum apa saja sepanjang system hukum itu menjunjung tinggi keadilan, persamaan, kebebasan, persaudaraan dan kemanusiaan yang menjadi inti syari'at Islam. Mereka bisa menerima system hukum yang bisa melindungi agama, bisa melindungi akal, keturunan, hak milik atau harta serta bisa melindungi jiwa. Syari'at Islam diterapkan secara terbuka, artinya syari'at Islam diterapkan sembari menerima "unsur-unsur luar" seperti adat setempat dan pemikiran-pemikiran yang berasal dari luar Islam. Syariat Islam bisa disebut terbuka karena ia bisa ditafsirkan oleh siapa saja. Tidak ada monopoli dalam penafsiran syari'at, dan karenanya tidak perlu ada perorangan atau lembaga "pengawas syari'at" yang memonopoli tafsir atas syari'at Islam secara otoriter.

Khaled Abou El-Fadl dalam bukunya Speaking in God's name, Islamic Law, Authority and Women (2014:202) menjelaskan tafsir otoriter sebagai berikut: authoritarianism is the act of locking or captivating the will of Divine or the will of the text into the specific determination as inevitable, final and conclusive.

Model ketiga, kombinasi, artinya dalam mengamalkan syari'at Islam, mereka akan melihat mana syari'at Islam yang sudah qath'iy al -wurud wa al-dilalah dan mana yang masih dzanni. Hanya sebagian dari syari'at Islam yang masih dzanni saja mungkin bisa diijtihadi sedangkan yang sudah pasti tidak perlu dan tidak bisa diijtihadi. Dalam konteks ini, mereka terkadang memilah-milah, antara hukum Islam yang bersifat privat ( personal law) dan hukum Islam yang bersifat publik. Pada hukum privat atau personal law mereka cenderung tekstualis, tapi dalam hukum publik mereka cenderung substansialis.

Pilihan yang diambil oleh masing- masing daerah atau negara akan sangat tergantung pada politik hukum yang dianut oleh daerah atau negara yang bersangkutan. Politik penerapan syari'at Islam dalam kehidupan berbangsa dan bernegara bisa dilihat dari konsensus politik dari para pendiri negara yang kemudian dituangkan dalam bentuk konstitusi atau hukum dasar bagi suatu negara yang dijadikan acuan bagi pembuatan hukum atau undang-undang dibawahnya.

Dalam tulisannya yang berjudul, Syari'at Islam, Konstitusi dan Hak Asasi Manusia, Nurrohman (2002:17) mengatakan bahwa dilihat dari hukum dasar atau konstitusi yang dirumuskan oleh sejumlah negara Muslim, setidaknya ada empat model konstitusi negara muslim. Pertama, negara Muslim (Muslim country) yang konstitusinya mengakui Islam sebagai agama negara dan menjadikan syari'at Islam sebagai sumber utama pembuatan undang-undang. Disini bisa dimasukkan negara seperti Saudi Arabia, Libya, Iran, Pakistan dan Mesir. Kedua, negara Muslim yang konstitusinya menyatakan Islam sebagai agama negara tetapi tidak menyebutkan syari'at sebagai sumber utama pembuatan undang-undang, artinya syari'at Islam hanya dipandang sebagai salah satu sumber dari beberapa sumber pembuatan undangundang, contohnya Irak dan Malaysia. Ketiga, negara Muslim yang tidak menjadikan Islam sebagai agama negara dan tidak menjadikan syari'at islam sebagai sumber utama pembuatan undang-undang tapi mengakui syari'at Islam sebagai hukum yang hidup di masyarakat, contohnya Indonesia. Keempat, negara Muslim yang menyatakan diri sebagai negara sekuler dan berusaha agar syari'at Islam tidak mempengaruhi system hukumnya, contohnya Turki.

Dalam bukunya yang berjudul Membaca Gelombang ljtihad; Antara Tradisi dan Literasi, Atho Mudzhar (1998:174-175) menyatakan bahwa gerakan pembaharuan dalam hukum keluarga di Negari-negeri Muslim di dunia ini pada dasarnya terbagi atas tiga kategori:

1. Negeri Islam yang sama sekali tidak mau melakukan pembaharuan dan masih tetap memberlakukan hukum keluarga sebagaimana tertuang dalam 
kitab-kitab fiqh dari madzhab yang dianut. Saudi Arabia adalah contoh dari negeri dalam kategori ini.

2. Negeri Islam yang sama sekali telah meninggalkan hukum keluarga Islam dan sebagai gantinya mengambil hukum sipil Eropa. Turki adalah contoh dalam kategori ini.

3. Negeri-negeri yang berusaha memberlakukan hukum keluarga Islam tetapi setelah mengadakan pembaharuan di sana sini. Mesir, Tunisia, Pakistan dan Indonesia adalah contoh dai negerinegeri dalam kategori ini.

Mudzhar mencatat setidaknya ada 13 masalah yang muncul saat berbicara tentang pembaharuan hukum keluarga di dunia Islam yaitu:

1. Masalah pembatasan umur minimal untuk kawin bagi laki-laki dan wanita dan masalah perbedaan umur antara pasangan yang hendak kawin.

2. Masalah peranan wali dalam nikah.

3. Masalah pendaftaran dan pencatatan perkawinan

4. Masalah keuangan perkawinan: mas kawin dan biaya perkawinan

5. Masalah poligami dan hak-hak istri dalam poligami

6. Masalah nafkah istri dan keluarga serta rumah tinggal

7. Masalah talak dan cerai di muka pengadilan

8. Masalah hak-hak wanita yang dicerai suaminya

9. Masalah masa hamil dan akibat hukumnya

10. Masalah hak dan tanggungjawab pemeliharaan anak setelah terjadi perceraian

11. Masalah hak waris, termasuk bagi anak dari anak yang telah terlebih dahulu meninggal.

12. Masalah wasiat bagi ahli waris

13. Masalah keabsahan dan pengelolaan wakaf keluarga.

Teori Penerapan Syariat Islam di Indonesia

Di Indonesia, sejumlah pakar berbeda pandangan dalam menjelaskan tentang bagaimana syariat Islam diterapkan dalam kon- tek system hukum nasional. Sejumah teori dikemukakan oleh sejumlah pakar.

Dalam bukunya yang berjudul Teoriteori Hukum Islam: Suatu Telaah Perbandingan dengan Pendekatan Filsafat, Juhaya S Praja (2009:107) guru besar Hukum Islam di Universitas Islam Negeri Sunan Gunung Djati Bandung menggunakan teori kredo untuk memahami perilaku umat Islam dalam menjalankan syari'at agamanya. Teori ini pada intinya mengatakan bahwa umat Islam, di mana pun mereka berada, akan berusaha menjalankan norma agama yang terdapat dalam syari'at Islam semata-mata karena tuntutan keyakinannya. Teori ini mirip dengan teori otoritas hukum dan teori personalitas. Menurut teori otoritas hukum yang dikembangkan oleh H.A.R.Gibb, orang Islam yang telah menerima Islam sebagai agamanya berarti telah menerima otoritas hokum Islam atas dirinya. Sedangkan dalam teori personalitas, seorang muslim selamanya terikat untuk melaksanakan hukum Islam dimana pun ia berada, baik di wilayah hukum dimana hokum Islam diberlakukan, maupun di wilayah hokum dimana hokum Islam tidak diberlakukan. Tokohnya adalah Imam Syafi'i (wafat $204 \mathrm{H} / 819 \mathrm{M})$

Menurut teori receptio in complexu, seorang Muslim memiliki kewajiban untuk melaksanakan seluruh hukum Islam sebagai bentuk konsekwensi syahadatnya. Menurut teori ini, bagi orang Islam yang berlaku penuh adalah hukum Islam sebab ia telah memeluk Islam walaupun dalam pelaksanaannya masih terdapat penyimpangan-penyimpangan. Teori ini dikembangkan oleh Lodewijk Willem Christian(LWC) Van Den Berg (18451927). Teori ini menjadi acuan dalam kebijaksanaan penjajah sejak tahun 1855.

Sedangkan menurut teori receptie, hukum Islam di Indonesia baru berlaku apabila hukum adat menghendaki hal tersebut. Tokohnya adalah Christian Snouck Hurgronye (1857-1936). Menurut R. Soepomo (2000:10) dalam bukunya Bab-bab Tentang Hukum Adat, teori ini merupakan hasil penelitian Hurgronye di Aceh dan Gayo. Teori ini menjadi acuan kebijakan colonial sejak tahun 1929 melalui Indische Staatsregeling tahun 1929 Pasal 134 ayat 2 yang berbunyi: 
“Dalam hal terjadi masalah perdata antar sesama orang Islam, akan diselesaikan oleh hakim agama Islam apabila hukum adat mereka menghendakinya."

Teori receptie exit merupakan kebalikan teori receptie. Inti dari teori ini adalah bahwa setelah Indonesia merdeka dan setelah UUD 1945 dijadikan UUD Negara, maka walaupun aturan peralihan menyatakan bahwa hokum yang lama masih berlaku selama jiwanya tidak bertentangan dengan UUD 1945, seluruh peraturan perundangundangan pemerintah Hindia Belanda yang berdasarkan ajaran receptie tidak berlaku lagi karena jiwanya bertentangan dengan UUD 1945. Sesuai UUD 1945 pasal 29 ayat 1 maka Negara Republik Indonesia berkewajiban membentuk hukum nasional Indonesia dengan bahan hukum agama. Negara mempunyai kewajiban kenegaraan untuk itu. Hukum agama yang masuk dan menjadi hukum nasional Indonesia itu bukan hukum Islam saja, melainkan juga hukum agama lain untuk pemeluk agama lain. Hukum agama di bidang perdata dan hukum pidana diserap menjadi hokum nasional Indonesia. Istilahnya hukum baru Indonesia dengan dasar Pancasila. Teori ini dikembangkan oleh Hazairin (1985:52) sebagai mana ditulis dalam bukunya berjudul Tujuh Serangkai tentang Hukum. Adapun teori receptio a contrario menyatakan bahwa bagi umat Islam berlaku hokum Islam, hukum adat baru berlaku apabila tidak bertentangan dengan hukum Islam. Tokohnya adalah Sayuti Thalib.

Selain itu ada pula teori teritorialitas. Bagi penganut teori ini seorang muslim terikat untuk melaksanakan hukum Islam sepanjang ia berada di wilayah hukum dimana hukum Islam diberlakukan. Dengan kata lain, hukum Islam hanya diberlakukan di wilayah teritorial negara yang memberlakukannya. Tokohnya adalah Imam Abu Hanifah. (wafat $150 \mathrm{H} / 767 \mathrm{M})$

Adapun menurut teori positivisasi hokum Islam, penerapan hukum Islam tidak lagi ditentukan atas dasar diterima oleh hukum adat. Sebab hukum Islam pada dasarnya sudah menjadi hukum positip bagi umat Islam Indonesia. Acuan utama teori ini adalah: UU No.1 th 1974 tentang perkawinan, PP No.28 th 1977 tentang perwakafan, UU Nomer 7 tahun 1989 tentang Peradilan Agama, Inpres No.1 th 1991 tentang Kompilasi hokum Islam, UU No.17 th 1999 tentang Pengelolaan Zakat. Tokohnya adalah A Qadri Azizy

Terakhir adalah teori eksistensi. Menurut teori ini hukum Islam dianggap telah ada atau telah diakomodir sepanjang disitu terdapat unsur, nilai atau tujuan yang hendak dicapai oleh hokum Islam seperti nilai keadilan, kemaslahatan, hikmah dan rahmat. Teori ini berasal dari Ibn Qayyim. (wafat 751H /1350 M)

\section{Strategi Memperjuangkan Transformasi Hukum Islam kedalam Hukum Nasional}

Memperjuangkan transformasi atau penyerapan hukum Islam kedalam hukum nasional memerlukan sejumlah strategi. Pertama, orientasinya mesti tertuju pada tujuan hukum Islam. Tujuan hukum Islam, sebagaimana telah disebutkan diatas adalah untuk melindungi hak-hak dasar manusia, menegakkan keadilan dan membawa kemashlahatan atau kebaikan untuk semua. Kedua, dalam upayanya melindungi hak dasar yang dimiliki manusia, maka hak-hak itu mesti dipilah untuk memastikan mana yang tergolong hak dasar yang primer, sekunder dan tersier. Ketiga, dalam upayanya untuk membawa keadilan dan kebaikan bersama, hukum Islam mesti bisa memperlihatkan fleksibilitasnya dengan menyesuaikan diri dengan situasi sosial politik yang selalu berubah.

Dengan kata lain, dalam melakukan transformasi hukum Islam mesti menggunakan multi model, tidak terpaku pada satu model. Tiga model penerapan syari'at Islam: model tekstualis eksklusif; substansialis inklusif; dan model kombinasi bisa digunakan semuanya tergantung situasi dan kondisinya. Model tekstulis eksklusif yang lebih menekankan dimensi simbolik atau attributive bisa diterapkan untuk wilayah privat, sedangkan model substansialis inklusif yang lebih menekankan dimensi normative substantive, bisa diterapkan untuk wilayah publik. Disini alat uji keberadaan syari'at Islam adalah teori eksistensi yang dirintis oleh Ibn Qayyim. Melalui teori ini, keberadaan syariat bisa dilacak melalui aturan-aturan yang adil, bijak, 
membawa kebaikan umum dan membawa rahmat bagi semuanya yang indikasinya bisa dilihat dari sejauh mana aturan itu telah bisa melindungi kaum minoritas, kelompok yang lemah dan terpinggirkan. Dalam kontek Indonesia, indikator syari'at yang membawa rahmat adalah bahwa syariat itu bisa menjamin terpenuhinya hak-hak konstiusional warga Negara Indonesia tanpa diskriminatif.

Transformasi hukum Islam kedalam hukum nasional tidak selalu mulus dan lancar. Hal ini bisa dijelaskan melalui dua hal. Pertama, fakta bahwa hukum Islam dalam sejarahnya telah tumbuh dan berkembang menjadi berbagai madzhab atau aliran. Aliran-aliran itu ada yang cenderung konservatif dan ada yang cenderung progresif. Kedua, proses penyerapan atau transformasi hukum Islam kedalam system hukum nasional disampaing melalui proses politik atau politik hukum yang dijadikan acuan di negeri ini juga mesti melalui uji publik.

Dalam proses politik, didalamnya terdapat sejumlah kelompok atau partai politik dengan orientasi politik atau ideology yang berbeda-beda. Kelompok politik dengan ideologinya masing-masing memiliki kepentingan yang berbeda dengan kepentingan hukum Islam, atau kepentingan hukum secara umum yakni mewujudkan keadilan dan kebenaran. Sebab sebagaimana dikatakan oleh Hans Kelsen (1949:xvi) setiap ideologi politik berakar pada kemauan untuk berkuasa (volition) bukan untuk membuat kesadaran pencerahan (cognition), berakar dalam emosi yang tidak rasional yang kemudian membentuk kesadaran bersama sebagai kami. Ideologi politik itu muncul dari kepentingan tertentu, atau, lebih tepatnya, dari kepentingan selain kepentingan kebenaran. (Every political ideology has its root in volition not in cognition, in the emotional, not in the rational, element of our consciuosness; it arises from certain interests, or, rather, from interest other than interest in truth.)

Dalam uji publik atau debat public, dalil dan argumentasi yang dikemukakan oleh masing-asing pihak yang berbeda perspektif sangat berperan. Pandangan yang didukung dengan dalil dan argumentasi yang kuat maka akan lebih berpengaruh. Dalam tradisi hukum Islam proses ini dilakukan melalui ijtihad dan ijma atau consensus. Dalam tulisannya yang berjudul Islam Challenges and Opportunities, Fazlur Rahman (1979:325) mengatakan sebagai berikut: ljtihad must be multiple effort of thinking minds -- some naturally better than others, and some better than others in various areas -- which confront each other in an open arena of debate, resulting eventually in overall consensus. Dalam kontek Indonesia, perdebatan yang bermuara pada kesepakatan atau consensus sejalan dengan spirit kerakyatan yang dipimpin oleh hikmat kebijaksanaan dalam permusyawaratan/perwakilan yang merupakan sila keempat dari Pancasila.

Dilihat dari perspektif Negara hukum dengan Pancasila sebagai ideologinya, maka ideology apapun atau system hukum apapun termasuk ideology Islam dan system hukumnya harus menyesuaikan diri dan harus siap mengalami proses pengujian konstitusional dengan tetap menjunjung tinggi nilai-nilai Pancasila. Artinya, dalam bahasa Masykuri Abdillah, ideology yang didasarkan pada agama harus menjadi sub ideology Pancasila.

Dengan kata lain, hukum apapun yang akan diserap kedalam hukum nasional mesti siap diuji melalui teori hukum murni atau "pure theory of law" yang diperkenalkan oleh Hans Kelsen. Teori ini bisa disebut sebagai "general theory of positive law". Menurut Kelsen (1949:xiii-xiv) hukum murni tidak boleh dipengaruhi oleh motif dan maksud para pembuat hukum atau kepentingan individu, kecuali motif dan tujuan yang memang sengaja diakomodir pada saat proses pembuatan hukum. Jadi, general theory dimaksudkan untuk membuat analisis struktural terhadap hukum positive yang ada, bukan penjelasan psikologis, ekonomis dalam kondisi tertentu, atau penjelasan moral dan politik. Sesuai dengan namanya "pure theory of law" teori ini berusaha menghindari elemen-elemen lain selain "specific method of science". Sain itu menggambarkan obyek apa adanya, bukan menggambarkan obyek sesuai dengan seharusnya menurut pandangan nilai-nilai tertentu. 


\section{Simpulan}

Syariat atau hukum Islam, bagi umat Islam merupakan jalan yang digariskan Tuhan untuk dijalani manusia dalam kehidupannya agar sesuai dengan kehendak Tuhan. Syariat adalah konsep praktis untuk berprilaku. Syariat atau hukum Islam memiliki sejumah karakter. Pertama, ia mengandung nilai sakral karena ia berasal dari Tuhan. Karakter kedua bahwa hukum Islam mengandung muatan moral. la tidak hanya berbicara hak dan kewajiban tetapi bebicara tentang apa yang sebaiknya diperbuat dan apa yang sebaiknya tidak diperbuat oleh seorang yang dewasa dan berakal sehat (mukallaf). Karakter ketiga ialah bahwa hukum Islam pada dasarnya bersifat personal. Sebab ia terkait dengan keimanan. Karakter keempat, hukum Islam tidak sepenuhnya bergantung pada Negara tertentu. Sebab ia dikembangkan oleh para pakar hukum. Negara tidak merumuskan hukum, Negara mengangkat hakim untuk melaksanakan hukum. Sistem hukum Islam merupakan varian ketiga dalam dikhotomi antara civil law dan common law. Karakter kelima, hukum Islam fleksibel dan dinamis. Sebab ia pada dasarnya bisa berubah jika terjadi perubahan sosial. la dinamis karena bisa berkembang sesuai dengan perkembangan peradaban umat manusia. ljtihad (individual reasoning) tetap terbuka sepanjang masa. Karakter, keenam adalah bahwa ia rasional, sebab meskipun ia berasal dari firman Tuhan, tapi dapat dipahami dan sejalan dengan akal sehat atau penjelasan sain.

Secara umum model penerapan syariat Islam di sejumlah negara bisa dibagi menjadi tiga yakni: model tekstualis eksklusif, substansialis inklusif dan model kombinasi. Penerapan syariat Islam di Indonesia telah mengundang munculnya banyak teori dari para pakar hukum yang kalau dikerucutkan dapat menjadi dua teori saja yakni teori receptie dan teori receptie in complexu.

Bagi kelompok Islamism atau kelompok yang menjadikan Islam sebagai ideology politik, strategi memperjuangkan transformasi hukum Islam kedalam hukum nasional dapat dilakukan melalui tiga cara. Pertama, dengan mengarahkan orientasinya pada tu- juan hukum Islam. Tujuan hukum Islam, sebagaimana telah disebutkan diatas adalah untuk melindungi hak-hak dasar manusia, menegakkan keadilan dan membawa kemashlahatan atau kebaikan untuk semua. Kedua, dalam upayanya melindungi hak dasar yang dimiliki manusia, prioritas dipilih pada hak dasar primer, kemudian baru yang sekunder dan tersier. Ketiga, dalam upayanya untuk membawa keadilan dan kebaikan bersama, hukum Islam mesti bisa memperlihatkan fleksibilitasnya dengan menyesuaikan diri dengan situasi sosial politik yang selalu berubah.

Dilihat dari perspektif Negara hukum berdasarkan Pancasila, ideology apapun atau system hukum apapun harus menyesuaikan diri dan harus siap mengalami proses pengujian konstitusional dengan tetap menjunjung tinggi nilai-nilai Pancasila. Artinya, ideology yang didasarkan pada agama harus menjadi sub ideology Pancasila.

\section{Daftar Pustaka}

Abd al-Raziq, Ali, 1985.al-Islam wa ushul al-Hukm; Bakhs fi al-khilafah wa al-hukumah, diterjemahkan menjadi Khilafah dan Pemerintahan dalam Islam, Bandung: Pustaka.

Abou El Fadl, Khaled et al. 2004. Islam and the Challenge of Democracy-Princeton University Press.

Abou El Fadl, Khaled, 2014. Speaking in God's Name: Islamic Law, Authority and Women, England: Oneworld Publications.

Abdillah, Masykuri,2000. "Agama dalam Pluralitas Masyarakat Bangsa" dalam Kompas 25-Februari.

Abed al-Jabri, Mohammad,2009. Democracy, Human Rights and Law in Islamic Thought -I. B. Tauris .

Alam, Lubna A,2007. Keeping The State Out: The Separation of Law and State in Classical Islamic Law, Michigan Law Review, April 2007, Vol. 105 Issue 6, p1255

Ash Shiddieqy, Hasbi, 1975. Filsafat Hukum Islam. Jakarta, Bulan Bintang.

Auda, Jasser,2007. Maqasid al-Shari'ah as Philosophy of Islamic Law, A Systems Approach, London, Washington: The International Institute of Islamic Thought,

Black, Ann, Esmaeili, Hussein and Hosen, Nadirsyah,2013. Modern Perspective on Islamic Law,UK: Edward Elgar Publishing Limited. 
Hazairin, 1985.Tujuh Serangkai tentang Hukum, Jakarta, Bina Aksara, cet.ketiga,

Kelsen, Hans,1949. General Theory of Law and State, Harvard University Press.

Mudzhar, Atho,1998. Membaca Gelombang ljtihad; Antara Tradisi dan Literasi, Yogyakarta: Titian Ilahi Press.

Nurrohman dkk,2002. Syari'at Islam, Konstitusi dan Hak Asasi Manusia: StudiTerhadap Pandangan Sejumlah Tokoh tentang Model Pelaksanan Syari'at Islam di Daerah Istimewa Aceh, Bandung: Lembaga Penelitian IAIN

Praja, Juhaya S.,2009. Teori-teori Hukum Islam: Suatu
Telaah Perbandingan dengan Pendekatan Filsafat, Bandung, Program Pascasarjana Universitas Islam Negeri (UIN)

Qayyim, Ibn, (tanpa tahun) .I'lam al-Muwaqi'in, jilid III, Bairut Dar al-Kutub al-Ilmia.

Rahman, Fazlur, 1979. Islam Challenges and Opportunities, dalam Islam: Past Influence and Present Challenge, Edited by Alford T. Welch and Piere Cachia, Edinburgh: Edinburgh University Press.

Soepomo, R.,2000. Bab-bab Tentang Hukum Adat, Jakarta: Pradnya Paramitha, cet kelima belas.

Watt, Montgomery, 1961. Muhammad Prophet and Statesman, Oxford University Press. 